\title{
Amifostine Protects Mouse Liver Against Radiation-induced Autophagy Blockage
}

\author{
MICHAEL I. KOUKOURAKIS ${ }^{1}$, ALEXANDRA GIATROMANOLAKI ${ }^{2}$, KONSTANTINA FYLAKTAKIDOU $^{3}$, \\ MARIA KOUROUPI ${ }^{2}$, EFTHIMIOS SIVRIDIS ${ }^{2}$, CHRISTOS E. ZOIS ${ }^{4}$, DIMITRA KALAMIDA ${ }^{1}$, \\ ACHILLEAS MITRAKAS ${ }^{1}$, STAMATIA POULILIOU $^{1}$, ILIAS V. KARAGOUNIS ${ }^{1}$, \\ KONSTANTINOS SIMOPOULOS ${ }^{5}$, DAVID J. P. FERGUSON ${ }^{4}$ and ADRIAN L. HARRIS ${ }^{4}$ \\ Departments of ${ }^{1}$ Radiotherapy/Oncology, ${ }^{2}$ Pathology, ${ }^{3}$ Molecular Biology and Genetics and \\ ${ }^{5}$ Experimental Surgery, Democritus University of Thrace/University \\ General Hospital of Alexandroupolis, Alexandroupolis, Greece; \\ ${ }^{4}$ CR UK Molecular Oncology Laboratories, Weatherall Institute of Molecular Medicine, \\ University of Oxford, Headington, Oxford, U.K.
}

\begin{abstract}
Background/Aim: Amifostine is the only selective normal tissue cytoprotector, approved for the protection against platinum toxicities and radiotherapy-induced xerostomia. Free radical scavenger and DNA repair activities have been attributed to the drug. Materials and Methods: We investigated the effect of amifostine on autophagy, lysosomal biogenesis and lipophagy of normal mouse liver exposed to clinically relevant doses of radiation. Results: The study provides evidence that ionizing radiation blocks autophagy activity and lysosomal biogenesis in normal mouse liver. Amifostine, protects the liver autophagic machinery and induces lysosomal biogenesis. By suppressing autophagy, ionizing radiation induces lipid droplet accumulation, while pre-treatment with amifostine protects lipophagy and up-regulates the TIP47 protein and mRNA levels, showing a maintenance of lipid metabolism in the liver cells. Conclusion: It is concluded that amifostine, aside to DNA protection activity, exerts its cytoprotective function by preventing radiation-induced blockage of autophagy, lysosomal biogenesis and lipophagy.
\end{abstract}

Exposure of cells to ionizing radiation results in DNA strand breaks leading to mutagenesis, apoptosis, senescence or mitotic catastrophe (1-3). Radiobiology research has been mainly orientated towards the identification of radioprotectors with free radical scavenger and DNA-repair

Correspondence to: Michael I. Koukourakis, Department of Radiotherapy - Oncology, Democritus University of Thrace, Alexandroupolis 68100, Greece. Tel: +30 2551351622, Fax: +30 2551030349, e-mail: targ@her.forthnet.gr

Key Words: Autophagy, lipophagy, lysosomal biogenesis, ionizing radiation, radioprotection, amifostine. activity. Currently, amifostine is the only FDA-approved, effective and normal tissue selective radioprotector, indicated for the protection against radiation xerostomia and platinum toxicities (4). Its activity has been postulated to occur due to free radical scavenger activity, as well as by accelerating the DNA repair process (4).

Although cytoplasmic organelles are also damaged by radiation (5-7), their role in the post-irradiation death/survival process remains poorly explored. Macro-autophagy (or for simplicity autophagy) is an important cytoplasmic cellular process that has been recently recognized as a principal death pathway involved in apoptosis-resistant cells (8). Failure to activate autophagy under damaging conditions leads to cell death, due to accumulation of damaged proteins and organelles, while autophagy over-activation also leads to cell death, revealing this pathway as a double-edged sword for cells exposed to stressful conditions, including exposure to radiation (9). Cytoplasmic energy resources, such as glycogen and lipid droplets also seem to be important in cell survival after various stresses $(10,11)$. Lipid droplets require autophagy to release lipids for the metabolic needs of normal and damaged cells (1214). Whether manipulation of autophagic flux would increase tolerance of vital body organs to radiation is unknown (8).

In the current study we investigated whether amifostine has an effect on the autophagic machinery, on lysosomal biogenesis and on lipophagic activity, using mouse liver as a model of experimentation.

\section{Materials and Methods}

Animal care and handling. Animal care and handling was carried out according to the guidelines set by Directive 86/609/EEC and the NIH Guide for the Care and Use of Laboratory Animals. All experimental procedures have been approved by the Veterinary Direction for Animal Research in the Department of Experimental 
Surgery at the Democritus University of Thrace. Male mice (Balb/c) 14 to 16 weeks of age $(33 \pm 2 \mathrm{gr})$, were under normal conditions concerning ambient temperature $\left(21-23^{\circ} \mathrm{C}\right)$, diet, tap water $a d$ libitum and were maintained on a $12 \mathrm{~h}$ light: $12 \mathrm{~h}$ dark cycle.

Mice were divided in groups of 5 and irradiated according to the protocol in Cobal60 $\gamma$-irradiation unit (dose rate $1.3 \mathrm{~Gy} / \mathrm{min}$ at $2 \mathrm{~cm}$ depth), receiving 3 daily fractions of $6 \mathrm{~Gy}$ of whole body irradiation. Mice treated with amifostine received $200 \mathrm{mg} / \mathrm{kg}$ of the drug $30 \mathrm{~min}$ before each radiotherapy fraction, using subcutaneous injection. Mice were followed daily with body weight measurement and symptom evaluation. Cohorts of mice were sacrificed on day 4 (72 $\mathrm{h}$ after irradiation) and on day 8 ( 7 days after irradiation) to obtain liver for molecular and microscopy analysis.

Liver tissue was removed and immediately placed in tubes containing RNAlater to inhibit protein and RNA degradation (Ambion, Thermo Fisher Scientific, Waltham, MA, USA) and stored at $-20^{\circ} \mathrm{C}$ for immunoblotting and RT-PCR. Tissue samples were also fixed in formalin and embedded in paraffin blocks for immunohistochemistry. Additional tissue samples were fixed in $4 \%$ glutaraldehyde in $0.1 \mathrm{M}$ phosphate buffer for electron microscopy studies.

Autophagy-lysosomal proteins analyzed. The current study focuses on key proteins related to autophagosomal formation, autolysosomal fusion and consumption and lysosomal genesis. Beclin1 is a key signaling molecule for initiation of autophagy. MAP1LC3A and MAP1-LC3B (microtubule-associated proteins 1A/1B light chain $3 \mathrm{~B}$ ) are main proteins of the autophagosomal membranes, that exist in two forms: LC3-I the soluble cytoplasmic one before the formation of autophagosomes and the LC3-II that resides on the lysosomal membranes. These two have different molecular weight and can be differentially assessed in western blot analysis. Sequestosome SQSTM1/p62 protein is a carrier of material for macro-autophagy that is degraded after auto-lysosomal fusion and its kinetics are used as a marker of autophagy flux. Transcription Factor TFEB is a master regulator of lysosomal genesis, also involved in the transcription of autophagy genes. Cathepsin-D is an intra-lysosomal enzyme involved in the digestion of autophagosomal content. LAMP2a is a protein of lysosomal membrane. TIP47/perilipin-3 is a protein of the lipid droplet membrane and is involved in lipophagy.

Tissue homogenization -Western blot. Liver tissues were collected, snap frozen in liquid nitrogen and stored at $-80^{\circ} \mathrm{C}$ until processed. Tissue homogenization in Ripa buffer (R0278, Sigma-Aldrich, St. Louis, MO, USA) led to whole cell protein lysates while homogenization of tissues in a sucrose-based lysis buffer $(0.25 \mathrm{M}$ sucrose, $1 \mathrm{mM}$ EDTA, $10 \mathrm{mM}$ Tris- $\mathrm{HCl}, \mathrm{pH}$ 7.4) followed by a differential centrifugation $(1000 \mathrm{~g} / 10 \mathrm{~min})$. Centrifugations led to double fractionation (nuclei $v s$. cytoplasm) or triple fractionation (supernatant where cytoplasmic-water soluble proteins exist, cytoplasmic pellet (cp) where cytoplasmic membrane proteins exist and, finally, nuclear where nuclear proteins are accumulated). Both lysis buffers were supplemented with 1 tablet/10 ml lysis buffer of complete protease inhibitor cocktail Tablets (11697498001, Roche, Basel, Switzerland), 0.1 ml phosphatase inhibitor cocktail 2 (P5726, Sigma, St. Louis, MO, USA), $0.1 \mathrm{ml}$ phosphatase inhibitor cocktail 3 (P0044, Sigma, St. Louis, MO, USA). Protein quantification of the fractions (whole, nuclear or non-nuclear) was performed according to Pierce BCA protein assay kit (\#23225, Thermo Scientific, Waltham, MA, USA) utilizing FLUOstar Omega filter- based multi-mode microplate reader (BMG Labtech, Offenburg, Germany). $30 \mu \mathrm{g}$ of the protein samples were separated on a discontinuous SDS gels using 10\% (for beclin-1, SQSTM1/p62, cathepsin-D, perilipin, TIP47, TFEB), $12.5 \%$ (forLC3A and LC3B), $8 \%$ (for lysosomal membrane protein LAMP2) separating and 5\% stacking gels.

All the groups were loaded on the same gel and transferred on the same membrane. After being blocked with 5\% non-fat dry milk in $150 \mathrm{mM} \mathrm{NaCl}, 10 \mathrm{mM}$ Tris, $\mathrm{pH} 7.5$ (TBS) at room temperature for 1 hour, the membranes were hybridized overnight at $4^{\circ} \mathrm{C}$ with antibodies to beclin1 (1:5000, ab62557, Abcam, Cambridge, UK), SQSTM1/p62 (1:5000, H00008878-M01, Novus Biologicals, Abingdon, UK), LC3A (1:5000, ab62720, Abcam, Cambridge, UK), LC3B (1:1000, LC3-5F10, NanoTools, Teningen, Germany), TFEB (1:1000, ab122910, Abcam, Cambridge, UK), LAMP2a (1:1000, ab18528, Abcam, Cambridge, UK), TIP47 perilipin/manose-6phosphate receptor (1:1000, ab47639, Abcam, Cambridge, UK), cathepsine-D (1:1000, ab5313-100, Abcam, Cambridge, UK). The LC3A and B antibody specificity were tested against the recombinant full-length proteins, which are commercially available from Novus Biologicals (Abingdon, UK) (15).

The membranes were then incubated for $2 \mathrm{~h}$ at room temperature with the appropriate secondary antibody, goat polyclonal to rabbit $\operatorname{IgG}(1: 10000$, ab6721, Abcam, Cambridge, UK) and rabbit polyclonal to mouse IgG (1:10000, NB 720-H, Novus Biologicals, Abingdon, UK) conjugated to HRP, and developed in Amersham ECL Western blotting detection reagents and analysis system (RPN2209, GE Healthcare, Little Chalfont, United Kingdom. To normalize our data each of these blots was stripped and re-hybridized with a polyclonal antibody to $\beta$-actin (1:15000, NB 600-532, Novus Biologicals, Abingdon, UK) in case of cytoplasmic protein detection or with polyclonal antibody to lamin B1 (ab133741, 1:3000, Abcam, Cambridge, UK) for nuclear protein detection, and processed as described above. The images of the blots were captured utilizing Chemidoc $^{\mathrm{TM}}$ MP imaging system (Bio-Rad, Hercules, CA, USA), and they were analysed by the accompanied Image Lab software. All experiments have been performed in triplicates.

Immunohistochemistry. The antibodies against the autophagic proteins LC3A (dilution 1:200; AP1905a, Abgent, San Diego, CA, USA) and LC3B (dilution 1:100; LC3-5F10, NanoTools, Teningen, Germany) were chosen among a panel of 8 commercial antibodies after western blot analysis (15); this was considered necessary to secure specific detection of LC3A and LC3B as several commercially available antibodies recognize these proteins. For the rest of the proteins the above used antibodies for immunoblot were also used for immunohistochemistry at the following dilutions: i) the anti-TFEB, rabbit polyclonal antibody (cat. no A303-673A; Bethyl Laboratories Inc, Montgomery, TX, USA), was used a dilution of 1:500 and overnight incubation, ii) the mouse monoclonal anti-cathepsin D, (CTD-19; Abcam, Cambridge, UK) antibody was used at a dilution 1:1000, at $30 \mathrm{~min}$ incubation, and iii) the rabbit polyclonal anti-LAMP2a antibody (ab18528; Abcam, Cambridge, UK) was used at a dilution or $1: 100$, at $30 \mathrm{~min}$ incubation, iv) The anti-rabbit polyclonal perilipin 3/TIP47 antibody (ab47638, Abcam, Cambridge, UK) was used at dilution 1:100 and $30 \mathrm{~min}$ incubation v) the mouse monoclonal ab56416 antibody (Abcam, Cambridge, UK) was used at dilution 1:200, 30 min incubation) 
Briefly, tissue sections were cut at $3 \mu \mathrm{m}$ from formalin-fixed paraffin-embedded tumors and mounted on poly-L-lysine coated glass slides. They were subsequently de-waxed and rehydrated in graded alcohols. Heat-induced epitope retrieval was achieved by placing the sections in citrate buffer (1:10 dilution, $\mathrm{pH} 7.2)$ and heated at $120^{\circ} \mathrm{C}$ for $3 \times 5 \mathrm{~min}$. Endogenous peroxidase activity was neutralized using peroxidase block for $5 \mathrm{~min}$. The non-specific binding was blocked by preincubation with protein block for $5 \mathrm{~min}$ at room temperature (Novocastra Laboratories Ltd, Newcastle upon Tyne, UK). The slides were then incubated overnight at $4^{\circ} \mathrm{C}$ with the primary antibodies at the dilutions indicated above.

After washes in phosphate-buffered saline (PBS) $(2 \times 5 \mathrm{~min})$, the sections were incubated with post primary block (that enhances penetration of the subsequent polymer agent) for $30 \mathrm{~min}$ at room temperature (Novocastra Laboratories Ltd, Newcastle upon Tyne, UK). They were subsequently washed in PBS for $2 \times 5 \mathrm{~min}$ and incubated with NovoLink polymer for $30 \mathrm{~min}$ at room temperature (Novocastra Laboratories Ltd, Newcastle upon Tyne, UK). This recognizes mouse and rabbit immunoglobulins and detects any tissuebound primary antibody. After thorough washing in PBS $(2 \times 5 \mathrm{~min})$, the color reaction was developed in 3,3'-diaminobenzidine (DAB) for $5 \mathrm{~min}$. The sections were then counterstained with hematoxylin, dehydrated and mounted. Known positive cancer tissues were used as controls. Normal immunoglobulin-G was substituted for the primary antibody as negative control. Staining with omission of the primary antibody was also performed as negative control.

RNA extraction, $c D N A$ synthesis and qPCR. Nucleospin RNA, (740955, Macherey-Nagel, Düren, Germany) was used for RNA extraction. A total of $10 \mathrm{mg}$ of tissue were homogenized using plastic pestle. For RNA harvesting, the homogenized tissue resuspended in $350 \mu \mathrm{l}$ RA1 buffer and $3.5 \mu \mathrm{l} \beta$-mercaptoethanol. Then, the steps of this kit were followed in order to achieve a high yield of RNA. The sample concentrations were measured using the NanoDrop 2000c (Thermo Scientific, Waltham, MA, USA) and RNA samples were stored at $-80^{\circ} \mathrm{C}$.

A total of $1 \mu \mathrm{g}$ of RNA and the Transcriptor First Strand cDNA synthesis kit (04379012, Roche, Basel, Switzerland) was used to perform cDNA synthesis. Firstly, a reaction which contains $1 \mu \mathrm{g}$ of RNA, $1 \mu \mathrm{l}(2.5 \mu \mathrm{M})$ of Oligo dT's and $\mathrm{H}_{2} \mathrm{O}$ to a total volume of $13 \mu \mathrm{l}$ was prepared. RNA was denatured using an incubation step, $10 \mathrm{~min}$ at $65^{\circ} \mathrm{C}$, followed by incubation on ice for $10 \mathrm{~min}$. Afterwards, the volume of the reaction was made up to $20 \mu$ by adding $1 \times$ Reaction buffer, $4 \mathrm{mM}$ ( $1 \mathrm{mM} /$ base $)$ dNTPs, 20 units of Protector RNase inhibitor and 10 units of Transcriptor Reverse Transcriptase. Finally, the reaction was incubated using the following conditions: $55^{\circ} \mathrm{C}$ for $30 \mathrm{~min}$ and $85^{\circ} \mathrm{C}$ for $5 \mathrm{~min}$. The cDNA samples were stored at $-20^{\circ} \mathrm{C}$.

In this study, the expression levels of the genes were measured using real-time quantitative PCR and SensiMix ${ }^{\text {TM }}$ SYBR No-ROX kit (QT650, Bioline, Taunton MA , USA) was used. The reaction of $20 \mu \mathrm{l}$ was prepared adding $1 \times$ of SensiMix ${ }^{\mathrm{TM}}$ SYBR No-ROX kit, $250 \mathrm{nM}$ of forward primer, $250 \mathrm{nM}$ of reverse primer. The suggested cycle conditions were used: 1 cycle at $95^{\circ} \mathrm{C}$ for $15 \mathrm{sec}$ and $40 \mathrm{cycles}$ at $95^{\circ} \mathrm{C}$ for $15 \mathrm{sec}, 55^{\circ} \mathrm{C}$ for $15 \mathrm{sec}$ and $72^{\circ} \mathrm{C}$ at 15 sec. All reactions were performed on Roche Light Cycler 480II in triplicates. The primer sets that were used, designed using Roche Primer design tool and presented analytically in Table I

The relative changes in transcriptional levels of all genes between control and different conditions were calculated using the comparative $\mathrm{Ct}$ method (2-ddCt) as the efficiencies of the target genes and reference gene are approximately equal near to $100 \%$.
Table I. Primer design tool for RT-PCR

\begin{tabular}{|c|c|c|}
\hline Primer name & $\begin{array}{l}\text { Primer Sequence }\left(5^{\prime}-3^{\prime}\right) \\
\text { Forward/Reverse }\end{array}$ & $\begin{array}{c}\text { Product } \\
\text { size }\end{array}$ \\
\hline MAP1LC3A & $\begin{array}{l}\text { GAC CAG CAC CCC AGT AAG AT } \\
\text { TGG GAC CAG AAA CTT GGT CT }\end{array}$ & $93 \mathrm{bp}$ \\
\hline MAP1LC3B & $\begin{array}{l}\text { CCC CAC CAA GAT CCC AGT } \\
\text { CGT TCA TGT TCA CGT GGT }\end{array}$ & $104 \mathrm{bp}$ \\
\hline Becn1 & $\begin{array}{l}\text { AGG ATG GTG TCT CTC GAA GAT T } \\
\text { GAT CAG AGT GAA GCT ATT AGC ACT TTC }\end{array}$ & $77 \mathrm{bp}$ \\
\hline Ctsd & $\begin{array}{l}\text { CCC TCC ATT CAT TCA TTG CAA GAT AC } \\
\text { TGC TGG ACT TGT CAC TGT TGT }\end{array}$ & $73 \mathrm{bp}$ \\
\hline P62/Sqtm-1 & $\begin{array}{l}\text { AGA CCC CTC ACA GGA AGG AC } \\
\text { CAT CTG GGA GAG GGA CTC AA }\end{array}$ & $103 b p$ \\
\hline Lamp2a & $\begin{array}{l}\text { GTG ACA AAA GGA CAG TAT TC TAC AGC } \\
\text { CCA ATA AAA TAA GCC AGC AAC A }\end{array}$ & $128 \mathrm{bp}$ \\
\hline Lamp2 & $\begin{array}{l}\text { AAG GTG CAA CCT TTT AAT GTG AC } \\
\text { TGT CAT CAT CCA GCG AAC AC }\end{array}$ & $70 \mathrm{bp}$ \\
\hline Tfeb (1) & $\begin{array}{l}\text { GAG CTG GGA ATG CTG ATC C } \\
\text { GGG ACT TCT GCA GGT CCT T }\end{array}$ & $118 \mathrm{bp}$ \\
\hline Tfeb (2) & $\begin{array}{l}\text { CAA GTT GCC GGA ACC TCA } \\
\text { ATG GCA GCT GTT GGT TCG }\end{array}$ & $79 \mathrm{bp}$ \\
\hline Tfeb (3) & $\begin{array}{l}\text { CTG TCC AAC CCC AGG CTA } \\
\text { GCT CTC GCT GCT CCT CCT }\end{array}$ & $124 b p$ \\
\hline Plin3 & $\begin{array}{l}\text { CCA CAG GAT GCT GAA AAG G } \\
\text { TGA TGT CCC TGA ACA TGC TG }\end{array}$ & $76 \mathrm{bp}$ \\
\hline Actb & $\begin{array}{l}\text { CTA AGG CCA ACC GTG AAA AG } \\
\text { ACC AGA GCA TAC AGG GAC A }\end{array}$ & $104 b p$ \\
\hline
\end{tabular}

ActB was used as a reference gene for the normalization of the results. The equation that were utilized presented below: $\mathrm{RQ}=2^{-\mathrm{ddCt}}$,

$\begin{aligned} \mathrm{ddCt}= & \left(\left(\mathrm{Ct}_{\text {target gene }}-\mathrm{Ct}_{\text {reference gene }}\right)_{\text {sample }}{ }^{-}\right. \\ & \left.\left(\mathrm{Ct}_{\text {target gene }}-\mathrm{Ct}_{\text {reference gene }}\right)_{\text {calibrator }}\right)\end{aligned}$

Confocal microscopy. Sections were cut at $2 \mu \mathrm{m}$ from fresh mouse liver tissues and mounted on poly-L-lysin coated slides. The samples were then stained with a sequential immunofluorescence staining protocol for LC3A (1:200, Abcam, Cambridge, UK), LC3B (1:100, Nanotools, Teningen, Germany), p62 (1:200, Abcam, Cambridge, UK), TFEB (1:500, Bethyl, Montgomery, TX, USA), LAMP2a (1:100, Abcam, Cambridge, UK), LAMP2b (1:100, Abcam, Cambridge, UK), TIP47 (1:200, Abcam, Cambridge, UK) proteins. In single staining process, the tissues slides were blocked in PBS $/ 5 \%$ w/v BSA pH 7.4 for $30 \mathrm{~min}$, primary antibodies were firstly incubated for $1 \mathrm{~h}$ at room temperature, washed in PBS $\mathrm{pH} 7.4$, incubated with the appropriate secondary antibody (1:250; Biotium) for $30 \mathrm{~min}$ at room temperature, followed by PBS washes, and finally the DNA was counterstained with Hoechst $33342(1 \mu \mathrm{g} / \mathrm{ml}$; Sigma-Aldrich, St. Louis, MO, USA) for $30 \mathrm{~min}$ at room temperature. After final washes with PBS, coverslips were mounted on the top of the samples using homemade Mowiol mounting medium.

In the case of double staining for co-localization imaging, the first primary antibody was firstly incubated for $1 \mathrm{~h}$ at room temperature. The slides were then washed in PBS pH 7.4, incubated with the appropriate secondary antibody (1:250; Biotium, Fremont, CA, USA) for $30 \mathrm{~min}$ at room temperature, followed by PBS washes. The 
samples were then blocked in PBS/5\% w/v BSA pH 7.4 for 20 min, and the second step of the sequential staining was performed using the second primary antibody for $1 \mathrm{~h}$ at room temperature. The slides were then washed in PBS pH 7.4, incubated with the appropriate secondary antibody (1:250; Biotium, Fremont, CA, USA) and the DNA was counterstained with Hoechst $33342(1 \mu \mathrm{g} / \mathrm{ml}$; SigmaAldrich, St. Louis, MO, USA) for $30 \mathrm{~min}$ at room temperature. After final washes with PBS, coverslips were mounted on the top of the samples using homemade Mowiol mounting medium.

Imaging was performed on a customized Andor Revolution Spinning Disk Confocal System built around a stand (IX81; Olympus) with a $60 \times$ lens and a digital camera (Andor Ixon+885) (CIBIT Facility, MBG-DUTH). Image acquisition was performed in Andor IQ 2 software. Optical sections were recorded every $0.3 \mu \mathrm{m}$. All confocal microscopy images presented in this work are $2 \mathrm{D}$ maximum intensity projections of z-stack images (ImageJ $1.47 \mathrm{v}$ National Institute of Health, USA).

Electron microscopy. On removal of the liver from experimental animals, small portions were removed and fixed in $4 \%$ glutaraldehyde in $0.1 \mathrm{M}$ phosphate buffer and processed for routine electron microscopy. In summary, the samples were post-fixed in osmium tetroxide, dehydrated in ethanol, treated with propylene oxide, and embedded in Spurr's epoxy resin. $1 \mu \mathrm{m}$ sections were stained with Azure A for light microscopy. Thin sections of selected areas were stained with uranyl acetate and lead citrate prior to examination in a Jeol 1200EX electron microscope.

Statistical analysis. Statistical analysis was performed using the GraphPad Prism 5.0 (GraphPad Software Inc., USA). The unpaired two-tailed $t$-test or the Wilcoxon matched pairs test were used to compare groups with continuous variable data, as appropriate. Oneway ANOVA non-parametric analysis (Kruskal-Wallis test) was also performed to test difference among groups of continuous variables. A $p$-value of $<0.05$ was used for significance.

\section{Results}

Amifostine effect on autophagy. Amifostine induced a strong colocalization of the LC3A/LAMP2a and of the LC3B/cathepsin$\mathrm{D}$ proteins, confirming increased auto-lysosomal fusion (Figure 1a). This is paralleled by the reduction of p62 protein levels at 30 min after injection, confirmed in western blot (Figure 1b) and confocal microscopy (Figure 1a). In western blot analysis, an increased expression of nuclear and cytoplasmic LC3A (at $30 \mathrm{~min}$ ) and of LC3B (at $60 \mathrm{~min}$ ) was noted (Figure 1b). Consumption of lysosomes was also evident by the strong reduction of cathepisn-D and LAMP2a protein levels at $60 \mathrm{~min}$ (Figure 1c). TFEB increases in the nuclei (at $30 \mathrm{~min}$ ) and in the cytoplasm (at $60 \mathrm{~min}$ ), showing an activation of lysosomal biogenesis process (Figure 1d). TIP47 lipid droplet marker is rapidly reduced after amifostine injection, showing an intensification of lipophagy (Figure 1c).

Autophagy kinetics - the 4th post-irradiation day. BALB/c mice were treated with three daily fractions of 6Gy total body irradiation. We analyzed the liver for the post- irradiation kinetics of expression of LC3A and LC3B proteins, structural components of autophagic vacuoles. In light and confocal microscopy, LC3A was expressed in the cytoplasm of mouse liver hepatocytes and sinusoids, giving a granular pattern corresponding to autophagosomes (Figure 2a). Nuclear expression of LC3A was also noted (Figure 2a) in confocal microscopy, in accordance with recent studies showing that LC3s are subject to trafficking between cytoplasm and nuclei (15-17).

On the 4th day after the first fraction of radiotherapy (the day after 3 whole body daily doses of 6Gy), LC3A autophagosomes accumulated in mouse hepatocytes, suggesting either a blockage of the autophagic activity or increased autophagosomal formation (Figure 2a). The nuclear LC3A staining was lost (Figure 2a), while the LC3A-II membrane-bound form accumulated in the cytoplasm (Figure $2 b)$. To exclude an increased turnover of LC3A-II, the p62/sequestrosome protein, expected to be degraded following auto-lysosomal fusion, was assessed. The levels of p62 protein were increased following irradiation, pointing to an autophagy blockage (Figure 2b). Of interest, the pro-LC3A form of protein (from which LC3A-I and II proteins are produced) was reduced, indicating a suppressed LC3A transcription or impaired translation, besides the autophagy activity blockage. RT-PCR did not show any reduction of the LC3A mRNA levels, supporting a translational dysfunction (Figure 2f).

LAMP2a, LAMP2b and Cathepsin D lysosomal protein expression $(18,19)$ and the TFEB (lysosomal transcription factor (20)) levels remained unaffected as assessed by western blot and confocal microscopy (Figure 2c and 2e). By RT-PCR, mRNA levels showed minor changes, with the exception of the sharp reduction of the TFEB3 mRNA $(p<0.001$; Figure 2f).

Effects of amifostine on autophagy kinetics - the 4th postirradiation day. The response patterns of liver to irradiation changed when mice were pretreated with amifostine. Following irradiation, the LC3A staining and LC3A-II protein levels were reduced in the cytoplasm of hepatocytes of amifostine treated mice to lower than basal levels (Figure 2a). The p62 expression levels were also reduced to lower than the basal levels noted in non-irradiated mice (Figure $2 b)$. These results point to an increased autophagic activity. Moreover, the lysosomal proteins were reduced in the cytoplasm to levels lower than basal, supporting high lysosomal consumption (Figure 2c). Dual LC3A/LAMP2a immunostaining was performed, showing a clear depletion of lysosomes with remnant LC3A+ autophagic vescicles in amifostine treated mice, whilst control irradiated mouse liver showed intense accumulation of distinct, non co-localizing, $\mathrm{LC}_{3} \mathrm{~A}^{+}$and LAMP $2 \mathrm{a}^{+}$vesicles (Figure 2e). An additional interesting finding was that LC3A expression was sustained at basal levels in the nuclei of hepatocytes, in amifostine 


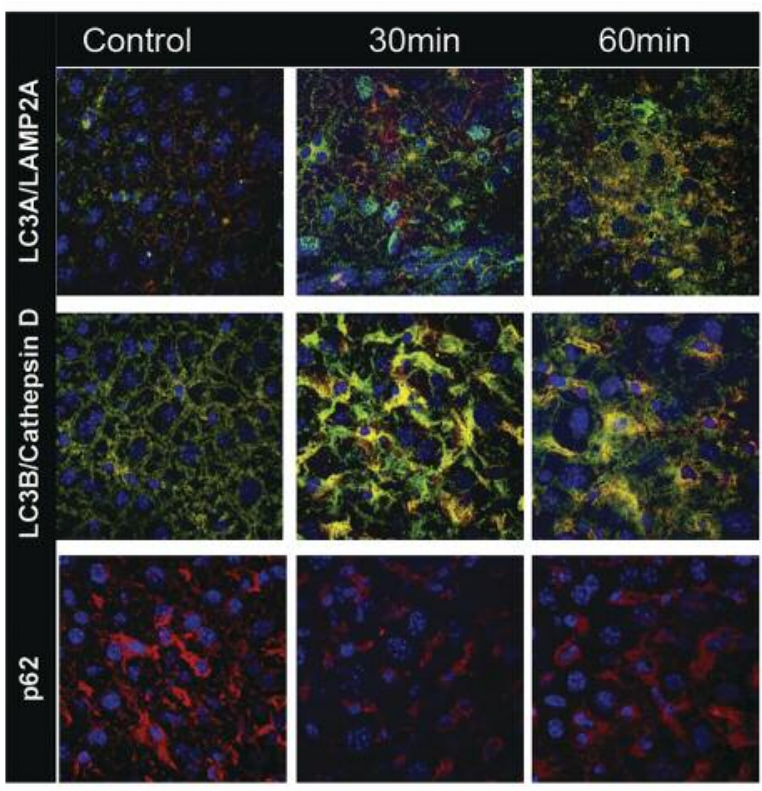

a

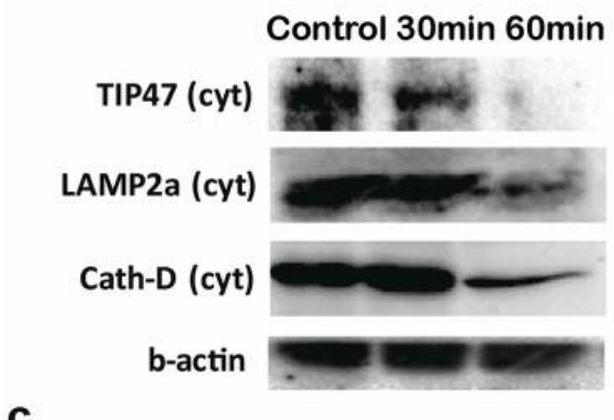

\section{Control 30min 60min}

LC3A (nuc)

LC3B (nuc)

lamin

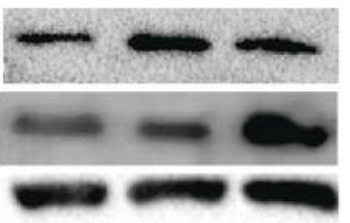

LC3A (cp)

LC3B (cp)

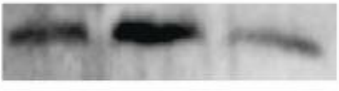

p62 (cp)

b-actin

b

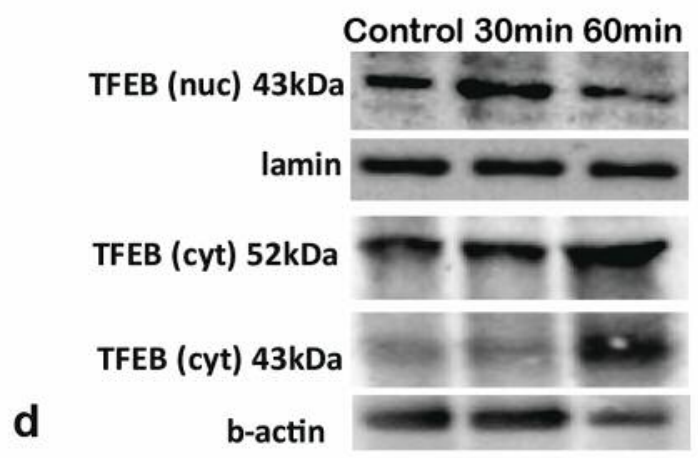

Figure 1. Amifostine effect on autophagy and lysosomal markers. a: Confocal microscopy of mouse liver before, 30 min and 60 min after subcutaneous administration of amifostine (LC3A green, LAMP2a red, LC3B red, Cathepsin-D green, p62 red, DAPI blue staining of nuclei); magnification $\times 60$. Amifostine had a strong effect stimulating autophagic activity in the liver of mice, with intensification of co-localization of LC3A/LAMP2a and LC3B/cathepsin D and reduction of p62 at 30 and 60 min after administration. $b$ : Western blot of LC3A, LC 3B and p62 proteins in the liver of mice, at 30 and 60 min following injection of amifostine. Assessment has been performed in nuclear (nuc) fraction and in cytoplasmic pellet ( $c p$ ) fraction (where auophagosomes reside), thus reflect the LC3-II form of the protein and auto-lysosomal p62, obtained after triple fractionation (nuclear, supernatant and cytoplasmic pellet fractionation). $c$ : Western blot in the cytoplasmic fraction of TIP47 lipid droplet marker and LCMP2a and cathepsin-D lsysosomal markers, showing a rapid reduction at 30 and 60 min, after amifostine injection. d: Western blot in nuclear and cytoplasmic fraction, of TFEB showing an increase in the nuclei at $30 \mathrm{~min}$ ) and in the cytoplasm at $60 \mathrm{~min}$.

treated mice, suggesting a new link between nuclear LC3A function and radioprotection (Figure 2a).

In contrast to mice treated with radiation alone, the irradiated liver of mice treated with amifostine showed a substantial increase of the TFEB 3 mRNA levels $(p<0.0001$; Figure 2f). Moreover, TFEB was reduced in the cytoplasm and increased in the nuclei, which supports an early response of the liver to enhance lysosome biogenetic activity under amifostine cytoprotection (Figure $2 \mathrm{c}$ and e).
Autophagy kinetics - the 8th post-irradiation day. Eight days following irradiation, LC3A was further reduced in the cytoplasm of hepatocytes in immunohistochemistry, compared to the 4th day, in mice receiving radiotherapy alone (Figure 2a). This was along with the reduction of the pro-LC3A in western blot analysis (Figure 2b). The LC3AII form and p62 protein levels remained higher than the control, but not as high as on the 4th day, which may show a low autophagic activity not compensated by induction of 
a

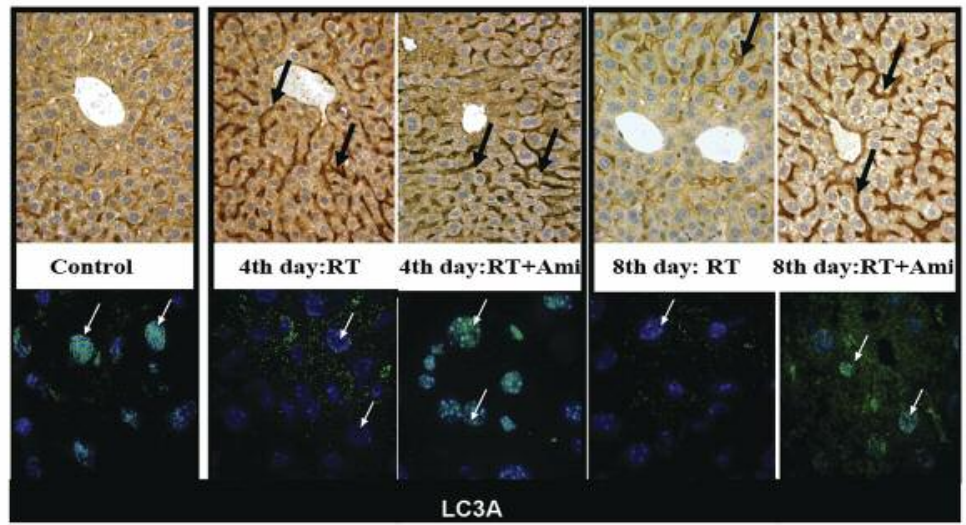

b
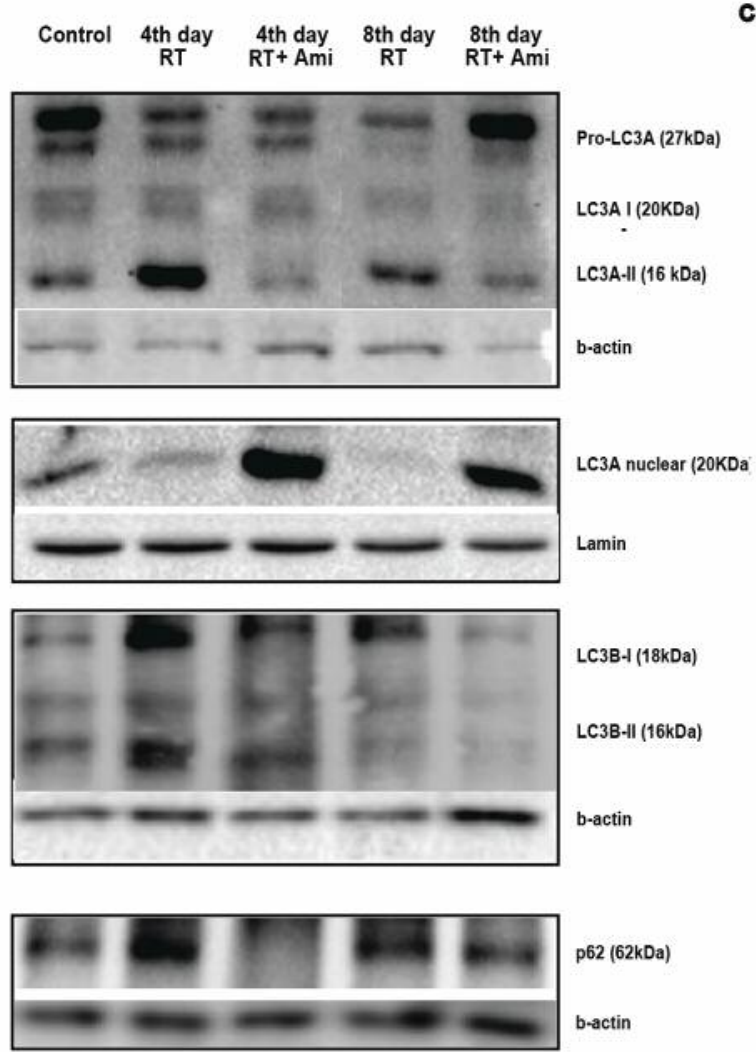
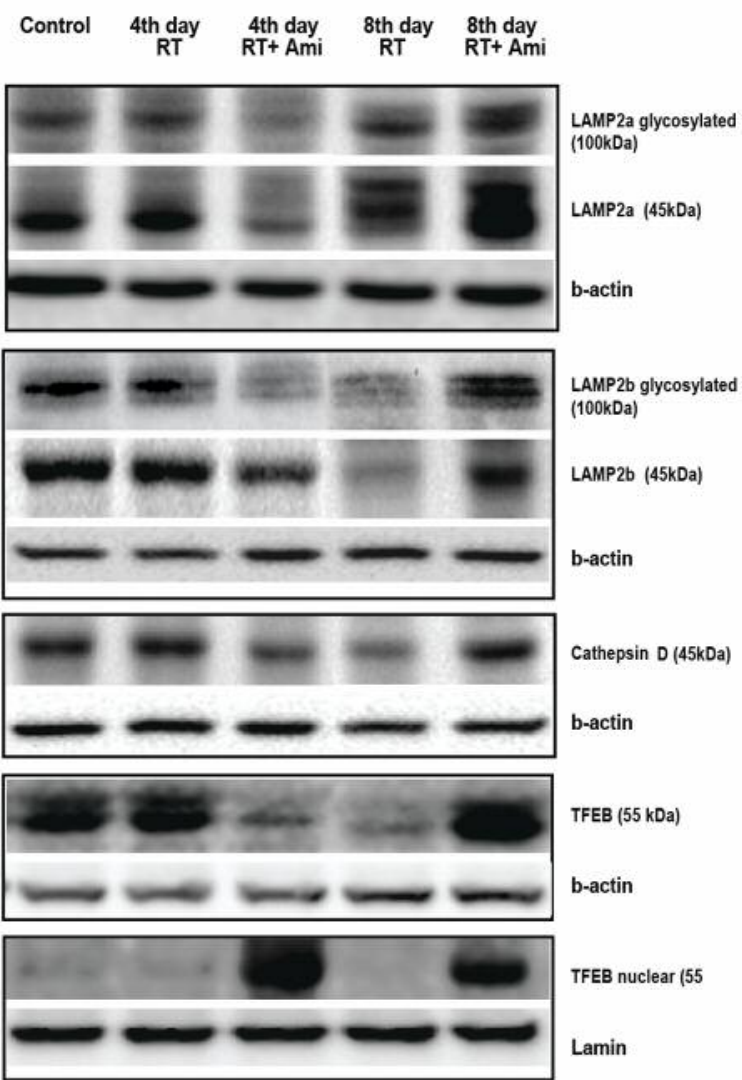

Figure 2. Continued lysosomal proteins. By RT-PCR, LC3A and p62 gene mRNA expression was reduced (Figure $2 \mathrm{f}$ ).

LAMP2a,b, cathepsin-D and TFEB lysosome related proteins were reduced compared to the 4th day (Figure 2b), compatible with the strong reduction of the expression of the related gene mRNA at the later 8 day time point (Figure 2f). In confocal microscopy, TFEB (nuclear and cytoplasmic) expression and LC3A/LAMP2a expression and colocalization was negligible, confirming the downregulation of autophagy and lysosome gene expression and of the autophagic activity (Figure 2e).

Effects of amifostine on autophagy kinetics - the 8th postirradiation day. On post-irradiation day 8, the LC3A staining 
d

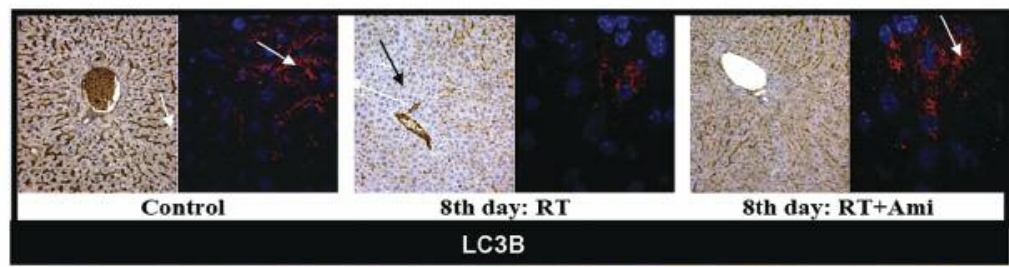

e
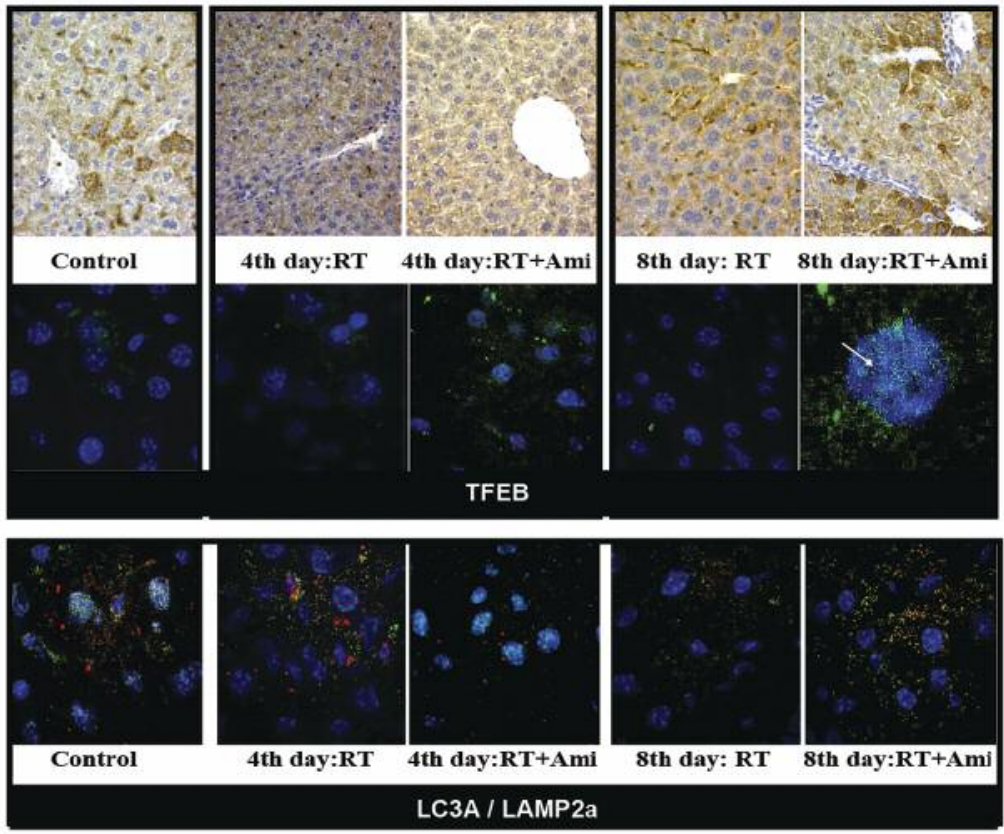

f

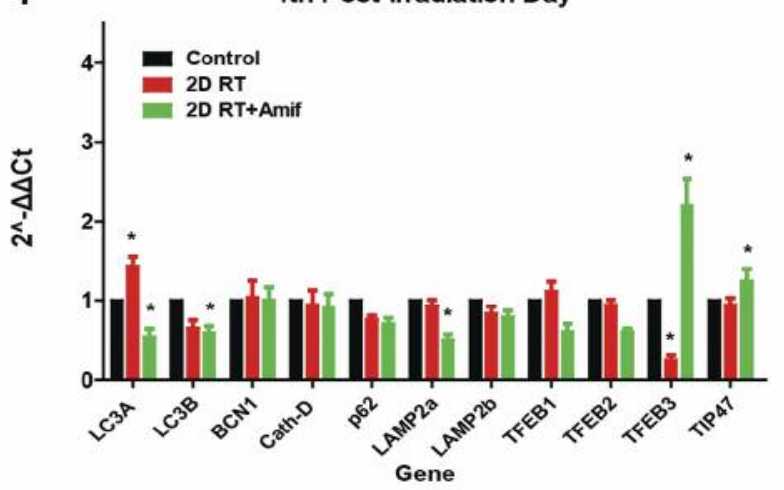

8th Post-irradiation Day

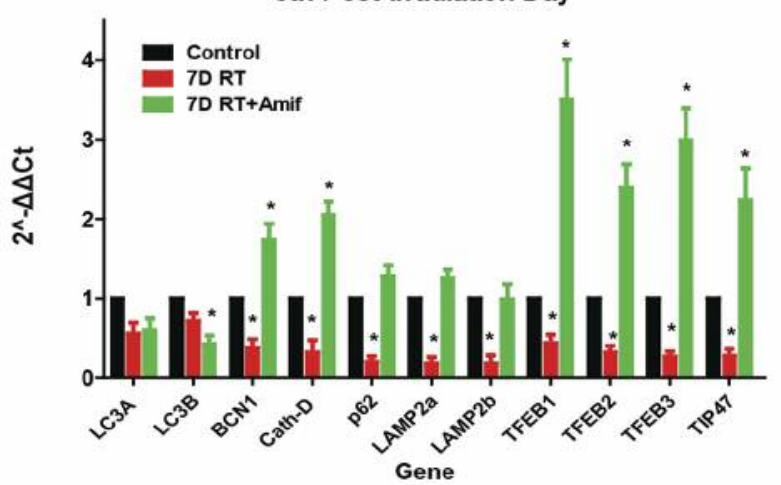

Figure 2. Effect of radiation (with and without pretreatment of mice with amifostine), on liver autophagy and lysosomal markers. a: LC3A immunohistochemical (magnification $\times 40$ ) and confocal immunofluorescence (magnification $\times 100)$ (LC3A green, LAMP2a red, TFEB green and DAPI blue staining of nuclei) images of mouse liver tissue, showing cytoplasmic expression in liver hepatocytes and sinusoids, before, on day 4 (72 h after irradiation) and day 8 (7 days after irradiation) after 3 fractions of $6 G y$ of whole body irradiation, with and without amifostine. Black arrows show the sinusoids. White arrows show nuclei of hepatocytes with or without localization of the protein (green staining of TFEB vs. blue DAPI staining without TFEB expression). $b$ : Western blot images of autophagy proteins (LC3A, LC3B and p62) as assessed in whole fraction (p62 and LC3B) or in nuclear vs. non-nuclear - cytoplasmic protein extracts (for LC3A) from mouse liver tissue before, on day 4 and day 8 after 3 fractions of 6Gy of whole body irradiation, with and without amifostine. $c$ : Western blot images of lysosomal proteins (TFEB, LAMP2a, LAMP2b and Cathepsin D) as assessed in whole fraction, from mouse liver tissue before, on day 4 and day 8 after 3 fractions of 6Gy of whole body irradiation, with and without amifostine. For TFEB, western blots refer to nuclear vs. non-nuclear protein extracts. d: LC3B immunohistochemical (magnification $\times 40$ ) and confocal immunofluorescence images (magnification $\times 100$ ) of mouse liver tissue, showing expression in liver sinusoids, before, on day 4 and day 8 after 3 fractions of $6 G y$ of whole body irradiation, with and without amifostine. White arrows show hepatic sinusoids stained for LC3B. e: TFEB immunohistochemical and confocal immunofluorescence images of mouse liver tissue, showing expression in liver sinusoids, before, on day 4 and day 8 after 3 fractions of $6 G y$ of whole body irradiation, with and without amifostine. Double immunofluorescence confocal microscopy images, detecting co-localization of LC3A and LAMP2a proteins, is also shown. White arrows show nuclear localization of the protein. $f:$ mRNA levels of the liver tissue of mice, on the 4th and 8th postirradiation days after irradiation with and without amifostine (* refers to a significant p-value $<0.05$; RT: irradiation). 


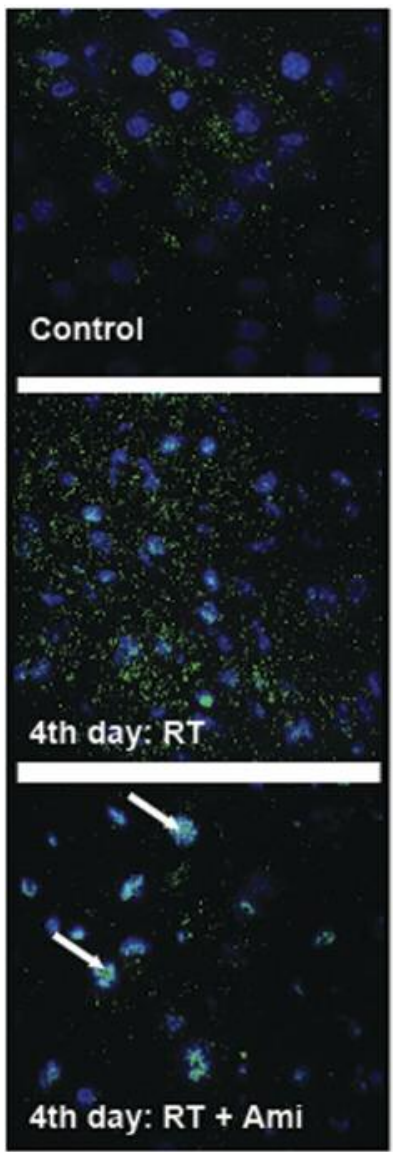

a

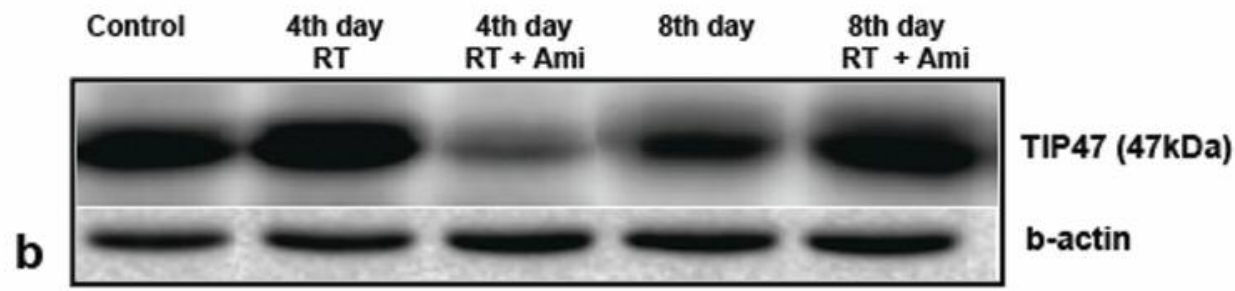

C
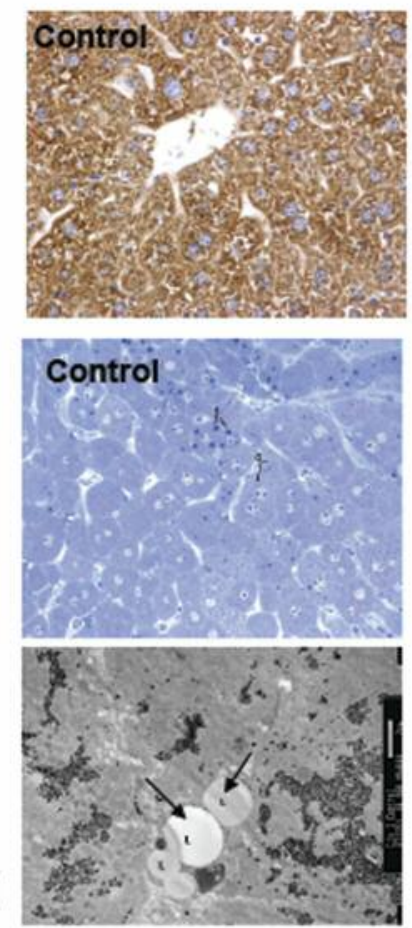
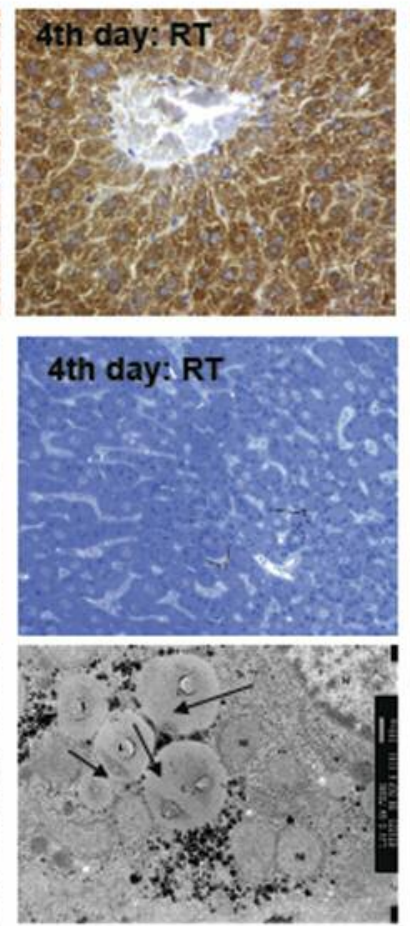
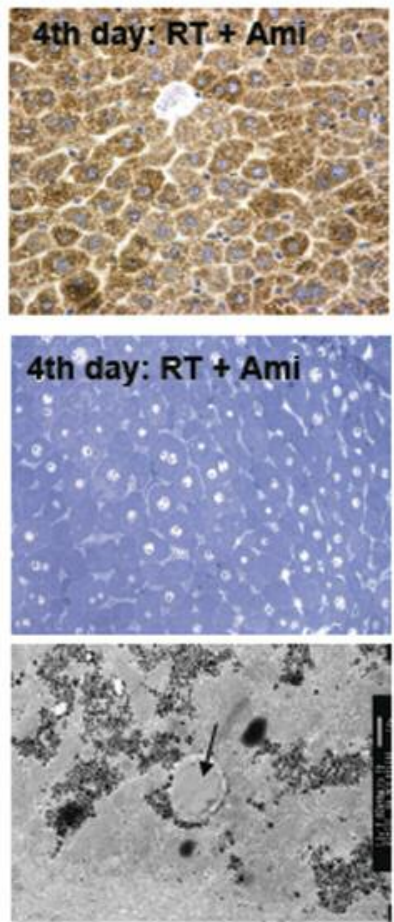

Figure 3. Effect of radiation (with and without pretreatment of mice with amifostine), on hepatocyte expression of TFEB and on lipid droplets. a: Confocal microscopy of TFEB expression (green) (magnification $\times 60$ ) in hepatocytes before and 3 days after irradiation without or with amifostine. DAPI blue staining shows the nuclei. TFEB is accumulated in the cytoplasm in the irradiated mice, whilst nuclear accumulation (arrows) is evident when amifostine was administered before irradiation. b: Western blot of TIP47/perilipin expression in mouse liver. On day 4, intense reduction of TIP47 levels is evident in irradiated mice when supported with amifostine, while overexpression occurs on day 8 (RT: irradiation). c: Immunohistochemical TIP47 expression in mouse liver showing accumulation in irradiated mice (magnification $\times 40$ ), whilst reduced expression is noted in mice receiving amifostine. $d$ : Electron microscopy images of mouse liver showing accumulation of lipid droplets in mouse hepatocytes on the 4th post-irradiation day, whilst reduced content is evident in hepatocytes of mice receiving amifostine before irradiation. Arrows show lipid droplets.

pattern showed a trend for normalization towards basal levels, in amifostine treated mice (Figure 2a). The LC3A-II protein levels were reduced and the pro-LC3A protein was strongly up-regulated compared to control mice (Figure 2b), suggesting a robust LC3A autophagy activity supported by LC3A production. Although this seems to contrast with the stable LC3A mRNA levels (Figure 2f), this may be a feedback from the high amounts of the LC3A-II protein released in the cytoplasm from lysed autophagosomes. Indeed, confocal microscopy confirmed high levels of the LC3A protein in the nuclei and cytoplasm of hepatocytes (Figure 2a).
Moreover, in amifostine treated mice, Beclin 1 (an early signaling step in autophagy), p62 and the lysosomal proteins and mRNA levels were highly expressed $(p<0.01)$ (Figure $2 \mathrm{~b}, 2 \mathrm{c}, 2 \mathrm{f}$ ) on a background of intensified LC3A/LAMP2a co-localization (Figure 2e), suggesting an increased production of autophagosomal and lysosomal proteins for functional autophagy. This is also supported by the observation that the lysosomal biogenesis TFEB transcription factor, was highly expressed, at protein and mRNA level $(p<0.0001)$, in the amifostine treated mice, with intense translocation to the nuclei (Figure 2c, 2d, 2f). In sharp contrast, the mRNA levels for all autophagy and lysosomal 
genes were strongly suppressed in mice treated with radiation alone $(p<0.01$; Figure $2 \mathrm{f})$.

$L C 3 B$ kinetics in the liver endothelium. LC3B was mainly expressed in the liver sinusoids (Figure 2d). Irradiation reduced LC3B expression in sinusoids in large patchy areas of the liver. This reduction was far less intense in amifostine treated mice (Figure 2d). The LC3B-II membrane boundform increased on the 4 th post-irradiation day, in parallel with p62 in the liver of mice that received irradiation without amifostine. This observation, indicating autophagy blockage, was absent in amifostine pretreated mice (Figure $2 b$ ). On day 8 , LC3B-II expression was very low in western blots, in sample treated with radiation alone, in the context of robust presence of LC3B-I, showing eventually a gradual exhaustion of existing autophagosomes in the context of a persistent reduced genesis of autophagosomes. In the amifostine group, LC3B-II and LC3B-I were both reduced, presumably reflecting an intense autophagosomal genesis and consumption.

Effect of radiation on hepatocyte lipid droplet content. Lipid droplets are dynamic organelles, possessing a monolayer membrane formed by the amphiphilic proteins of the perilipin/PLIN/PAT protein family, such as perilipin 1 (PLIN1), adipophilin (PLIN2) and PLIN3/TIP47 (21). Lipolysis of lipid droplets occurs either by cytosolic lipase activation or by lipophagy through the formation of autophagic vacuoles on the lipid droplet monolayer and fusion of lipid containing autophagosomes with lysosomes rich in acidic lipases (22). Consistent with the above mentioned blocking effect of radiation on the autophagic activity, PLIN3/TIP47 protein increased in liver of mice 4 days after irradiation compared to non-irradiated liver, but a reduction of staining intensity was noted in irradiated mice pre-treated with amifostine (Figure $3 \mathrm{a}, \mathrm{b}, \mathrm{c}$ ). This shows that 4 days after irradiation liver lipid droplet consumption is blocked, but this is reversed if mice are pre-treated with amifostine, where an intense consumption occurs. On day 8 , the liver of mice that received radiation alone showed a clear recovery of the process by reducing the TIP47 levels, thus intensifying lipid droplet consumption. In amifostine treated mice, TIP47 returned to normal levels, but this rather reflects continuation of lipid droplet consumption in the context of an intensified TIP47 transcription, as at the 8th postirradiation day, TIP47 mRNA levels were highly expressed in amifostine treated mice, whilst reduced levels were evident in mice treated with radiotherapy alone (Figure 2f).

Electron microscopy confirmed that lipid droplets were significantly accumulated following radiotherapy, whilst amifostine pre-treated mice exhibited reduced lipid droplet content at levels rather below the one noted in non-irradiated liver (Figure 3d). This shows that radiotherapy induces lipid droplet accumulation, and this is in direct relation with autophagy suppression, whilst in amifostine treated mice lipid droplets are used due to an intensified autophagic activity.

\section{Discussion}

Here we provide evidence that radiotherapy suppresses autophagy and this is a novel mechanism involved in radiation induced normal tissue toxicity. LC3A and LC3B proteins are structural components of the autophagic vacuoles (15). These derive from a proLC3 30KDa protein after cleavage by autophagin Atg4a to its active cytosolic form LC3-I. Following activation by Atg7, LC3-I is transferred to Atg3 giving rise to the membrane-bound form LC3-II that resides in the inner and the outer autophagosomal membranes. Following fusion with lysosomes, the outer LC3-II is released to the cytosol, while the inner is degraded by lysosomal hydrolases (23). LC3-I and II kinetics, are a marker of autophagic activity (24), especially when combined with the levels of the p62/sequestosome protein, a carrier-protein that initiates the formation of the autophagic vacuole, the levels of which decline under increased autophagic flux, due to its hydrolysis by the lysosomal enzymes.

As an early response to liver irradiation, $\mathrm{LC}^{+} \mathrm{A}^{+}$ autophagosomes and the LC3A-II form of protein accumulated in the cytoplasm of hepatocytes, in parallel with an increase of p62 protein levels, compatible with a blockage of autophagy. The pro-LC3A form of protein was reduced, which may indicate an early blockage of translation by ionizing radiation, as suppression of translational activity by radiation has been postulated in previous studies, although the mechanism has not been fully elucidated $(25,26)$. This early blockage of autophagy was subsequently accompanied by suppression of mRNA transcription for genes involved in autophagy and lysosomal biogenesis, including Beclin-1, p62, cathepsin-D, LAMPs and TFEB, which was evident 8 days after irradiation. Of interest, this late response of transcriptional repression parallels the nadir of cell growth exhibited around the 6th-8th day after irradiation, in all cell lines we have examined (data not shown). In a previous study of ours, irradiation of endothelial cells led to autophagy flux blockage, which is in accordance with the current data (27). In a study by Gobunov et al. (28), irradiation resulted in increased accumulation of LC3 in small intestine cells, which has been interpreted as increased autophagy. However, accumulation of LC3 may also be a result of reduced autophagy flux.

These response patterns changed when mice were premedicated with amifostine, (4) which accelerated the autophagic activity, and opposed the suppressive effect of radiation on the hepatocyte autophagic machinery. The mRNA levels of lysosomal genes (LAMP2a,b and 
Table II. Effects of therapeutic doses of ionizing radiation of liver auto-lysosomal activity.

\begin{tabular}{|c|c|c|}
\hline Time point & Events & Comments \\
\hline \multicolumn{3}{|c|}{ Irradiation without Amifostine } \\
\hline \multirow[t]{6}{*}{ 4th day } & $\begin{array}{l}\text { Accumulation of LC3A+ autophagosomes and of p } 62 \\
\text { protein in the cytoplasm of hepatocytes }\end{array}$ & Blockage of the LC3A auto-lysosomal activity \\
\hline & $\begin{array}{l}\text { Reduction of the pro-LC3A form in the cytoplasm in } \\
\text { the context of increased LC3A mRNA transcription }\end{array}$ & Reduction of translation \\
\hline & Disappearance of the LC3A from the nuclei & $\begin{array}{l}\text { Suggests a cytoplasmic/nuclear feedback that } \\
\text { induces LC } 3 \text { A transcription }\end{array}$ \\
\hline & $\begin{array}{l}\text { LAMP2a, LAMP2b and Cathepsin-D lysosomal protein expression } \\
\text { and the TFEB (transcription factor levels remained unaffected }\end{array}$ & $\begin{array}{l}\text { Reduced lysosomal consumption } \\
\text { (blockage of autophagy) }\end{array}$ \\
\hline & $\begin{array}{l}\text { LC3B is reduced in in the liver sinusoids, while the LC3B-II } \\
\text { form and the p62 protein were increased }\end{array}$ & $\begin{array}{l}\text { Blockage of auto-lysosomal activity and reduced } \\
\text { production of the LC3B protein in liver sinusoids }\end{array}$ \\
\hline & Increased expression of TIP47 and accumulation of lipid droplets & Blockage of lipophagy \\
\hline 8th day & $\begin{array}{l}\text { Further reduction of the pro-LC3A and LC3A-II forms in hepatocytes, } \\
\text { in parallel with reduced LC3A transcription compared to day } 4 \\
\text { Strong repression of multiple gene transcription and related protein } \\
\text { levels (Beclin-1, p62, LAMP2a, LAMP2b, Cathepsin-D, TFEB) }\end{array}$ & $\begin{array}{l}\text { An attempt of auto-lysosomal activity } \\
\text { restoration in absence of transcriptional support } \\
\text { Severe repression of auto-lysosomal } \\
\text { gene expression }\end{array}$ \\
\hline \multicolumn{3}{|c|}{ Irradiation with Amifostine } \\
\hline \multirow[t]{4}{*}{ 4th day } & $\begin{array}{l}\text { Reduced expression of the LC3A-II form in the cytoplasm, in parallel } \\
\text { with reduction of p } 62 \text { protein and reduced LC3A/LAMP2a structures }\end{array}$ & Intensified LC3A auto-lysosomal activity \\
\hline & $\begin{array}{l}\text { Reduced expression of lysosomal proteins LAMP2a, LAMP2b, } \\
\text { Cathepsin-D and TFEB in the cytoplasm of hepatocytes }\end{array}$ & Intensifies lysosomal consumption \\
\hline & Increased expression of nuclear TFEB and of TFEB 3 mRNA & Intensification attempt of lysosomal genesis \\
\hline & Lipid droplet reduction and Increased expression of TIP47 mRNA & $\begin{array}{l}\text { Lipid droplet consumption and attempt to } \\
\text { support of lipid droplet genesis }\end{array}$ \\
\hline \multirow[t]{5}{*}{ 8th day } & $\begin{array}{l}\text { Strong activation of multiple gene transcription and related protein } \\
\text { levels (Beclin-1, p62, LAMP2a, LAMP2b, Cathepsin-D, TFEB) }\end{array}$ & $\begin{array}{l}\text { Increased expression of autophagy and } \\
\text { lysosome protein encoding genes }\end{array}$ \\
\hline & $\begin{array}{l}\text { Strong expression of pro-LC3A, restoration of LC3A-II and p62 protein } 1 \\
\text { evels and re-appearance of LC3A/LAMP2a colocalizing structures }\end{array}$ & $\begin{array}{l}\text { Restoration of autophagosomal and } \\
\text { auto-lysosomal content }\end{array}$ \\
\hline & $\begin{array}{l}\text { Strong expression of lysosomal proteins LAMP2a, LAMP } 2 b \text {, } \\
\text { Cathepsin-D and TFEB in the cytoplasm of hepatocytes }\end{array}$ & Restoration of lysosomal content \\
\hline & Strong expression of TFEB in the nuclei & Intensified lysosomal genesis \\
\hline & $\begin{array}{l}\text { Intense transcription of the TIP } 47 \text { mRNA and expression of } \\
\text { the protein in the cytoplasm }\end{array}$ & Effective lipid droplet re-formation \\
\hline
\end{tabular}

cathepsin-D) and regulatory transcription factor TFEB were highly increased 8 days after irradiation in amifostine treated mice. A suppressive effect of radiation on LC3B protein kinetics, mainly expressed by the liver sinusoids was observed after irradiation alone and amifostine also protected the autophagic machinery of the liver vasculature. The observation that a short window of induction of autophagy by amifostine, only for 1 hour, was sufficient to protect autophagic machinery of the liver vasculature implies that the damaged organelles are produced by direct damage from the initial dose, rather than delayed metabolic effects. Indeed, amifostine per se has a strong effect on the autophagic activity evident within $30 \mathrm{~min}$ following injection. We recently reported that amifostine triggers HIF1 $\alpha$ expression and anaerobic metabolism within $30 \mathrm{~min}$ after administration in mice, an effect that involves amifostine interactions with mitochondria (29). Whether this pathway is also the cause of amifostine-mediated intensification of the auto-lysosomal machinery, demands further investigation. However, the sustained intensified autophagy activity for at least 8 days after irradiation suggests that an unknown, long-acting mechanism, is also activated or at least protected.

Whether a short acceleration of the autophagic activity minutes after amifostine injection is enough to enhance this long acting post-irradiation reparative mechanism or whether it is due to prevention of the initiation mechanism is unknown This pathway may be related to a tissue response to radiation dose levels low-enough to produce an easily reparable damage. The $6 \mathrm{~Gy}$ applied per fraction herein, is 
obviously a quite high dose for the mouse liver to adequately activate reparative autophagy within the interfraction intervals allowed, an event that is permitted only under the radioprotective effect of amifostine. In our experience, total body irradiation with 3 fractions of $6 \mathrm{~Gy}$ is lethal for BALB/c mice $(2 \times 6$ Gy is lethal for $80 \%$ of mice), while amifostine allows survival even after $4 \times 6$ Gy total body irradiation, as previously reported (30). This hypothesis opens a new field of research on cell and tissue specific response pathways to different fractions of radiation, focusing on the postirradiation kinetics of reparative autophagy. For example, a certain dose per fraction may be inadequate to block autophagy in a tissue, but may well block autophagy in a specific tumor, which defines an individualized radiation dose level per fraction to optimally treat a patient. Moreover, a dose per fraction that does not block autophagy in cancer cells may be inappropriate to achieve tumor eradication, so that if a higher dose per fraction is demanded to block autophagy in cancer, amifostine may prove of help to selectively protect the adjacent normal tissues from autophagy blockage.

Of interest, radiation induced a metabolic blockage in terms of lipid droplet usage by liver cells, identified as early as 3 days after irradiation. Accumulation of lipid droplets was induced, while pretreatment with amifostine protected lipophagy, as shown in electron microscopy and by the reduction of the TIP47 protein levels. On day 8 , a significant up-regulation of the TIP47 mRNA and protein levels was noted only in amifostine treated mice, potentially a response to the increased turnover of the protein. Again, the longacting mechanism that triggers reparative autophagy, seems also to involve lipophagy, as a component of the cell postirradiation survival process.

This finding that ionizing radiation at therapeutic dose levels leads to a profound impairment of the autophagic activity and suppression of genes involved in autophagy and lysosomal biogenesis in mouse liver, that persists up to at least 8 days after irradiation, opens new areas of clinical research. Table II summarizes the molecular events supporting the above conclusion. By increasing liver radiotolerance, chemoresistant liver metastasis or primary hepatomas could be treated by higher doses of radiation $(31,32)$.

\section{Conflicts of Interest}

The Authors declare no potential conflicts of interest.

\section{Acknowledgements}

The study was funded by the «TRAINING AND LIFELONG LEARNING - ARISTEIA» project, code no 520, ESPA 2007-2013, GGET decision number 12605/26.09.2012 and the Welcome Trust and Cancer Research UK.

\section{References}

1 Roos WP and Kaina B: DNA damage-induced cell death by apoptosis. Trends Mol Med 12: 440-450, 2006.

2 Sabin RJ and Anderson RM: Cellular senescence - its role in cancer and the response to ionizing radiation. Genome Integr 2: 7, 2011.

3 Eriksson D and Stigbrand T: Radiation-induced cell death mechanisms. Tumour Biol 31: 363-372, 2010.

4 Koukourakis MI: Amifostine in clinical oncology: current use and future applications. Anticancer Drugs 13: 181-209, 2001.

5 Yoshida $\mathrm{T}$, Goto $\mathrm{S}$, Kawakatsu $\mathrm{M}$, Urata $\mathrm{Y}$ and $\mathrm{Li} \mathrm{TS}$ : Mitochondrial dysfunction, a probable cause of persistent oxidative stress after exposure to ionizing radiation. Free Radic Res 46: 147-153, 2012.

6 Somosy Z: Radiation response of cell organelles. Micron 31: $165-181,2000$

7 Zhang B, Wang Y, Pang X, Su Y, Ai G and Wang T: ER stress induced by ionising radiation in IEC-6 cells. Int J Radiat Biol 86: 429-435, 2010

8 Zois CE and Koukourakis MI: Radiation-induced autophagy in normal and cancer cells: towards novel cytoprotection and radiosensitization policies? Autophagy 5: 442-450, 2009.

9 Koukourakis MI, Mitrakas AG and Giatromanolaki A: Therapeutic interactions of autophagy with radiation and temozolomide in glioblastoma: evidence and issues to resolve. Br J Cancer 114: 485-496, 2016.

10 Favaro E and Harris AL: Targeting glycogen metabolism: a novel strategy to inhibit cancer cell growth? Oncotarget 4: 3-4, 2013.

11 Przybytkowski E, Joly E, Nolan CJ, Hardy S, Francoeur AM, Langelier $\mathrm{Y}$ and Prentki M: Upregulation of cellular triacylglycerol - free fatty acid cycling by oleate is associated with long-term serum-free survival of human breast cancer cells. Biochem. Cell Biol 85: 301-310, 2007.

12 Devos P and Hers HG: Random, presumably hydrolytic, and lysosomal glycogenolysis in the livers of rats treated with phlorizin and of newborn rats. Biochem J 192: 177-181, 1980.

13 Kalamidas SA and Kotoulas OB: Studies on the breakdown of glycogen in the lysosomes: the effects of hydrocortisone. Histol Histopathol 15: 29-35, 2000.

14 Dong $\mathrm{H}$ and Czaja MJ: Regulation of lipid droplets by autophagy. Trends Endocrinol Metab 22: 234-240, 2011.

15 Koukourakis MI. Kalamida D, Giatromanolaki A, Zois CE, Sivridis E, Pouliliou S, Mitrakas A, Gatter KC and Harris AL: Autophagosome Proteins LC3A, LC3B and LC3C have distinct subcellular distribution kinetics and expression in cancer cell lines. PLoS One 10: e0137675, 2015.

16 Drake KR, Kang M and Kenworthy AK: Nucleocytoplasmic distribution and dynamics of the autophagosome marker EGFPLC3. PLoS One 5: e9806, 2010.

17 Dou Z. Xu C, Donahue G, Shimi T, Pan JA, Zhu J, Ivanov A, Capell BC, Drake AM, Shah PP, Catanzaro JM, Daniel Ricketts M, Lamark T, Adam SA, Marmorstein R, Zong WX, Johansen T, Goldman RD, Adams PD and Berger SL: Autophagy mediates degradation of nuclear lamina. Nature 527: 105-109, 2015.

18 Bandyopadhyay U, Kaushik S, Varticovski L and Cuervo AM: The chaperone-mediated autophagy receptor organizes in dynamic protein complexes at the lysosomal membrane. Mol Cell Biol 28: 5747-5763, 2008. 
19 Tatti M, Motta M, Di Bartolomeo S, Cianfanelli V and Salvioli $\mathrm{R}$ : Cathepsin-mediated regulation of autophagy in saposin $\mathrm{C}$ deficiency. Autophagy 9: 241-243, 2013.

20 Settembre C, Di Malta C, Polito VA, Garcia Arencibia M, Vetrini F, Erdin S, Erdin SU, Huynh T, Medina D, Colella P, Sardiello M, Rubinsztein DC and Ballabio A: TFEB links autophagy to lysosomal biogenesis. Science 332: 1429-1433, 2011.

21 Straub BK, Stoeffel P, Heid H, Zimbelmann R and Schirmacher P: Differential pattern of lipid droplet-associated proteins and de novo perilipin expression in hepatocyte steatogenesis. Hepatology 47: 1936-1946, 2008.

22 Singh R and Cuervo AM: Lipophagy: connecting autophagy and lipid metabolism. Int. J Cell Biol 2012: 282041, 2012.

23 Kabeya Y, Mizushima N, Ueno T, Yamamoto A, Kirisako T, Noda T, Kominami E, Ohsumi $\mathrm{Y}$ and Yoshimori T: LC3, a mammalian homologue of yeast Apg8p, is localized in autophagosome membranes after processing. EMBO J 19: 5720$5728,2000$.

24 Klionski DJ et al: Guidelines for the use and interpretation of assays for monitoring autophagy (3rd edition). Autophagy 12: 1222, 2016.

25 Trivigno D, Bornes L, Huber SM and Rudner J: Regulation of protein translation initiation in response to ionizing radiation. Radiat Oncol 8: 35, 2013.

26 Braunstein S, Badura ML, Xi Q, Formenti SC and Schneider RJ: Regulation of protein synthesis by ionizing radiation. Mol Cell Biol 29: 5645-5656, 2009.

27 Kalamida D, Karagounis IV, Giatromanolaki A and Koukourakis MI: Important role of autophagy in endothelial cell response to ionizing radiation. PLoS One 9(7): e102408, 2014.
28 Gorbunov NV and Kiang JG: Up-regulation of autophagy in small intestine Paneth cells in response to total-body gammairradiation. J Pathol 219: 242-252, 2009.

29 Koukourakis MI, Giatromanolaki A, Zois CE, Kalamida D, Pouliliou S, Karagounis IV, Yeh TL, Abboud MI, Claridge TD, Schofield CJ, Sivridis E, Simopoulos C, Tokmakidis SP and Harris AL: Normal tissue radioprotection by amifostine via Warburg-type effects. Sci Rep 6: 30986, 2016.

30 Zois CE, Giatromanolaki A, Sivridis E, Tokmakidis SP, Botaitis S, Simopoulos C, Kortsaris A and Koukourakis MI: Narrow amifostine dose windows define radioprotection outcome, following fractionated whole-body irradiation of mice. In Vivo 25: 191-196, 2011.

31 Leibel SA, Guse C, Order SE, Hendrickson FR, Komaki RU, Chang CH, Brady LW, Wasserman TH, Russell KJ, Asbell SO et al: Accelerated fractionation radiation therapy for liver metastases: selection of an optimal patient population for the evaluation of late hepatic injury in RTOG studies. Int J Radiat Oncol Biol Phys 18: 523-528, 1990.

32 Tanguturi SK, Wo JY, Zhu AX, Dawson LA and Hong TS: Radiation therapy for liver tumors: ready for inclusion in guidelines? Oncologist 19: 868-879, 2014.
Received October 27, 2017

Revised November 13, 2017

Accepted November 14, 2017 